\title{
Labellum structure of Bulbophyllum echinolabium J.J. Sm. (section Lepidorhiza Schltr., Bulbophyllinae Schltr., Orchidaceae Juss.)
}

\author{
Natalia Wiśniewska ${ }^{1} \cdot$ Monika M. Lipińska $^{2} \cdot$ Marek Gołębiowski $^{3} \cdot$ Agnieszka K. Kowalkowska $^{1}$
}

Received: 30 May 2018 / Accepted: 26 March 2019 / Published online: 16 April 2019

(C) The Author(s) 2019

\begin{abstract}
This micromorphological, chemical and ultrastructural study is a continuation of research conducted on the section Lepidorhiza. The Bulbophyllum echinolabium flowers comprised features that characterize a sapromyophilous syndrome, having large, glistening parts that emit an intense scent of rotten meat. The secretory activity was described in the hypochile (nectary in longitudinal groove and in the prickles) and the epichile (putative osmophore). The ultrastructural studies revealed a dense cytoplasm in the epidermis and subepidermal tissue with large nuclei and numerous mitochondria, the profiles of SER and RER, and dictyosomes. Large amounts of heterogeneous residues of secreted material (possibly phenolic) were present on the cuticle surface, similar to the unusual prominent periplasmic space with flocculent secretory material. The chemical analysis (GC/ MS) of the scent profile of lips comprised carbohydrates and their derivatives (29.55\% of all compounds), amino acids (1.66\%), lipids $(8.04 \%)$ and other organic compounds $(60.73 \%)$. A great number of identified compounds are Diptera attractants (mainly Milichiidae, Tephritidae, Drosophilidae, Muscidae, Sarcophagidae, Tachinidae). The examination of visual and olfactory features indicates correlation between colour of flowers and the type of olfactory mimicry, where a dark colour labellum emits strong smell of rotten waste.
\end{abstract}

Keywords Histochemistry $\cdot$ Micromorphology $\cdot$ Ultrastructure $\cdot$ GC/MS $\cdot$ Sapromyophily $\cdot$ Fly-pollination syndrome

Floral scent, colour and texture are important attractants for pollinators, such as flies, imitating their brood and feeding sites (Dobson 2006). The strong smell in sapromyophilous flowers acts as a long-distance attractant and helps flies find the flowers hidden in vegetation. Colour and texture interplay with the floral scent (Jürgens et al. 2006). Calliphoridae and Sarcophagidae flies prefer yellow flowers with the presence of a sweet odour, which signals their food sources, or brownpurple colour in combination with an excrement odour, which

Handling Editor: Hanns H. Kassemeyer

Agnieszka K. Kowalkowska

agnieszka.kowalkowska@biol.ug.edu.pl

1 Department of Plant Cytology and Embryology, Faculty of Biology, University of Gdańsk, Wita Stwosza 59, 80-308 Gdańsk, Poland

2 Department of Plant Taxonomy and Nature Conservation, Faculty of Biology, University of Gdańsk, Wita Stwosza 59, 80-308 Gdańsk, Poland

3 Laboratory of Analysis of Natural Compounds, Department of Environmental Analytics, Faculty of Chemistry, University of Gdańsk, Wita Stwosza 63, 80-952 Gdańsk, Poland signals egg-laying sites (Dobson 2006). Specialized devices, such as motile elements of the perianth, support pollination accuracy and effectiveness (Christensen 1994; Borba and Semir 1998; Vogel 2001; Kowalkowska et al. 2015a). The fly-pollinated orchids (myophilous or sapromyophilous) are described in the genus Bulbophyllum Thou. Bulbophyllum lasianthum Lindl. (section Beccariana Pfitz.), Bulbophyllum lobbii Lindl. (section Sestochilos Benth \& Hook.f.) and Bulbophyllum virescens J.J. Sm. (section Beccariana) (Ong and Tan 2011) are pollinated by blow flies (Calliphoridae). Flesh flies (Sarcophagidae) pollinate Bulbophyllum mandibulare Rchb.f. (section Lepidorhiza Schltr.) (Ong and Tan 2012), Bulbophyllum subumbellatum Ridl. and B. virescens (Ong and Tan 2011), both from section Beccariana. Whereas fruit flies, such as Bactrocera spp., are reported from Bulbophyllum baileyi F. Muell. (section Sestochilos) (Tan and Nishida 2007).

Bulbophyllum sect. Lepidorhiza comprises 28 species, with Borneo, Sulawesi, the Philippines and New Guinea as the main centres of diversity, growing in lowland or montane forests at elevations up to $1900 \mathrm{~m}$ a.s.l. (Pridgeon et al. 2014). In representatives of this section, the secretory tissue is located superficially in the well-defined, longitudinal, 

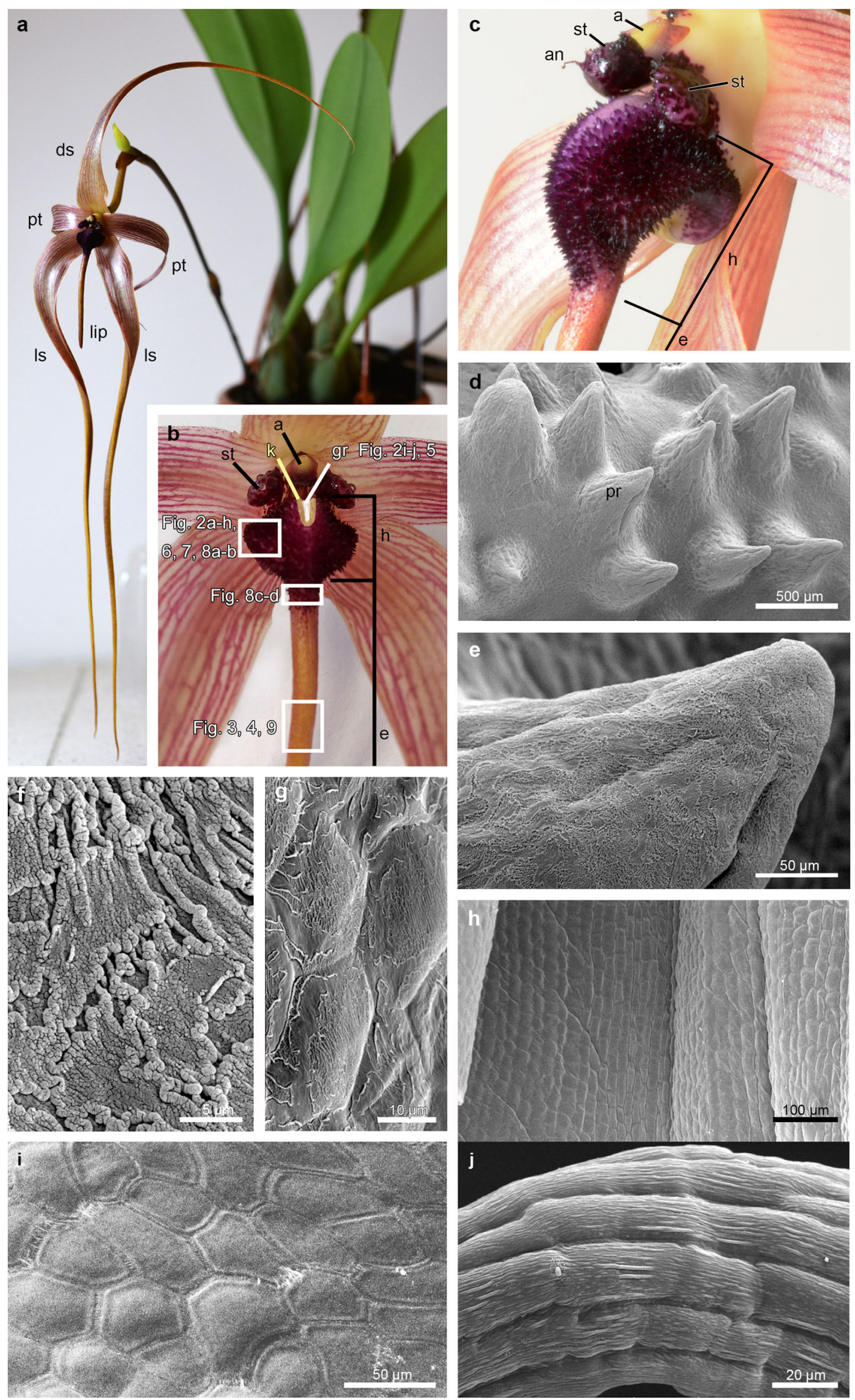
Fig. 1 Macro and micromorphological features of flowers of Bulbophyllum echinolabium. a Flower. b, c Details of the flower. $\mathbf{d}$ The adaxial (inner) surface of the hypochile composed by prickles. $\mathbf{e}$ Detail of $\mathbf{d}$, the prickle. f, $\mathbf{g}$ Fragmented cuticle on the adaxial surface of the epidermis: apical (f) and basal (g) part of prickle. h Smooth cells on the abaxial (outer) surface of the epichile. i Inner (adaxial) smooth surface of the stelidia. $\mathbf{j}$ Detail of the appendage of the stelidium with elongated cells. $a$ anther-cap, an appendage of stelidium, $d s$ dorsal sepal, $e$ epichile, $g$ gynostemium, $g r$ groove (marked with white on $\mathbf{b}$ ), $h$ hypochile, $k$ keel (marked with yellow on b), $l s$ lateral sepal, $p r$ prickle, $p t$ petal, $s t$ stelidium

median lip groove, which is a highly conservative lip feature among Bulbophyllum, in contrast to the nature of the secretion (Teixeira et al. 2004; Nunes et al. 2014; Kowalkowska et al. 2015a; Wiśniewska et al. 2018). In Bulbophyllum representatives, groove secretion has been identified as nectar, e.g. Bulbophyllum epiphytum (section Micranthae Barb. Rodr.), Bulbophyllum glutinosum (section Napellii Rchb.f.), Bulbophyllum regnellii (section Napellii), Bulbophyllum rothschildianum (section Cirrhopetalum Lindl.) (Teixeira et al. 2004) and Bulbophyllum wendlandianum (section Cirrhopetalum Lindl. or Cirrhopetaloides Garay, Hamer \& Siegerist) (Kowalkowska et al. 2015a), a protein-rich mucilaginous secretion in the section Racemosae (Davies and Stpiczyńska 2014) or a mucilaginous secretion in Bulbophyllum weberi (section Cirrhopetalum) (Kowalkowska et al. 2017). The scent glands (osmophores) occur on the apices of tepals, as the swollen tips of tepal appendages or as unicellular trichomes on labellar lobes (i.e. Teixeira et al. 2004; Kowalkowska et al. 2015b). In the previously examined Bulbophyllum levanae and Bulbophyllum nymphopolitanum from the section Lepidorhiza (Wiśniewska et al. 2018), the putative osmophores, based on phenols detected in the plastoglobuli of plastids, were located on the extended apices of sepals and possibly on petals. An abundance of proteins detected in the labellum of both species is most likely associated with the unpleasant scent of the flowers, whereas the lipid-rich cuticular striations formed a thin wax layer on the epidermis which is presumably involved in the brilliance of floral tepals, strongly attracting flies (Kugler 1951, apud Meve and Liede 1994). The presence of predominant periplasmic spaces in secretory cells with heterogeneous material gathered beneath the cuticle occurs in the labellum epidermis in these two species (Wiśniewska et al. 2018).

Bulbophyllum echinolabium J.J. Sm. (section Lepidorhiza) is endemic to the Indonesian island of Sulawesi, where it appears to be restricted to a single range of hills (Wood 2005). It is known for its flowers, which reach up to $35 \mathrm{~cm}$ long (possibly the largest flowers in the genus) and are borne from an inflorescence that may attain $70 \mathrm{~cm}$ in height. The labellum is reddish with a dark purple, thick, fleshy, carunculate-echinate hypochile and a smooth epichile, which is canaliculate with revolute margins (Wood 2005). The flowers of B. echinolabium imitate a highly unpleasant smell of rotten waste, which is characteristic of sapromyophilous flowers.

The proposed studies are the continuation of an anatomical survey of species from the section Lepidorhiza. The aims of the present work were (a) to verify the presence of secretion in labellum; (b) to examine in detail the secretory tissue; (c) to compare the anatomical similarities and differences in the micromorphology, anatomy and ultrastructure of secretory tissue of B. echinolabium with previously published B. levanae and B. nymphopolitanum (Lepidorhiza) (Wiśniewska et al. 2018); and (d) to characterize the floral scent profile and compare results in order to verify if there is a correlation between colour of flowers and the type of olfactory mimicry. This is the first anatomical study of the secretory tissue of $B$. echinolabium. Provided studies will give more insight into understanding fly-pollination syndrome.

\section{Materials and methods}

Tissue samples were collected from fresh flowers at anthesis from the greenhouse at the University of Gdańsk, Faculty of Biology (voucher numbers: AKK 2016-001, ML 2375).

To fix plant material $2.5 \%(v / v)$, glutaraldehyde $(\mathrm{GA})$ in $0.05 \mathrm{M}$ cacodylate buffer $(\mathrm{pH}=7.0)$ was used. Material for light microscopy (LM) following fixation was rinsed with cacodylate buffer and then dehydrated in an ethanol series. Then, the material was embedded in methylmethacrylatebased resin (Technovit 7100, Heraeus Kulzer GmbH). Sections were cut with glass knives (5-7 $\mu \mathrm{m}$ thick) using a Sorvall MT 2B and a Leica EM UC 7 ultramicrotomes and mounted on glass slides. Transverse sections were presented from different portions (apical, middle and basal in epichile, groove and keel, prickles on the hypochile).

For histochemical analysis, semi-thin control sections for light microscopy were stained with $0.05 \%(w / v)$ aqueous Toluidine Blue O (TBO, C.I. 52040) (Feder and O'Brien 1968; Ruzin 1999). Aniline Blue Black (ABB, C.I. 20470) was used for the detection of water-insoluble proteins (Jensen 1962). The Periodic Acid-Schiff reaction (PAS) was used to identify the presence of water-insoluble polysaccharides (Jensen 1962). A $0.05 \%(w / v)$ aqueous Ruthenium Red (C.I. 77800) solution and a $10 \%(w / v)$ aqueous solution of $\mathrm{FeCl}_{3}$ were used to test for pectic acids/mucilage (Johansen 1940) and catechol-type dihydroxyphenols (Gahan 1984), respectively. The preparations were examined and photographed with a Nikon Eclipse E 800 light microscope and a Nikon DS-5 Mc camera using Lucia Image software (University of Gdańsk, Poland). The sections, following $\mathrm{FeCl}_{3}$ staining, were observed using the differential interference contrast (DIC) imaging. Auramine O (C.I. 41000) $0.01 \%$ $(w / v)$ solution in $0.05 \mathrm{M}$ buffer Tris/ $\mathrm{HCl}, \mathrm{pH}=7.2$ was used to 

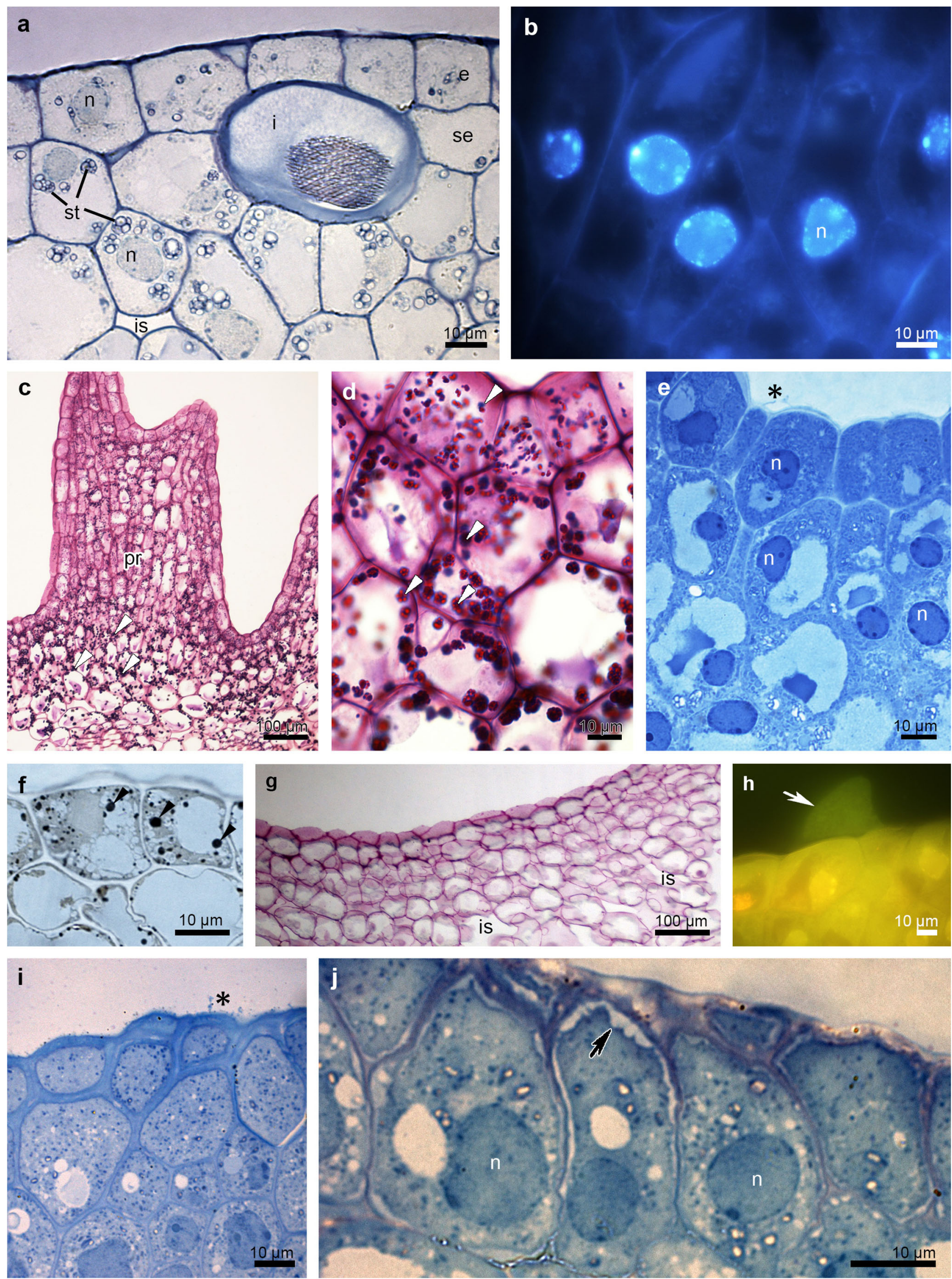
4 Fig. 2 Histochemical features of the adaxial surface of the hypohile: the prickles $(\mathbf{a}-\mathbf{h})$ and the groove $(\mathbf{i}, \mathbf{j})$ of $B$. echinolabium. a Transverse section showing a single-layered epidermis and subepidermal cells and idioblasts with raphides (TBO). b Subepidermal cells with enlarged nuclei (DAPI). c Abundance of starch grains (white arrowheads, PAS). d Detail of c. e The epidermis and subepidermal tissue stained intensively for proteins (ABB), note the secretory material on the surface (black asterisk). f Lipid drops (black arrowheads) (SBB). g Staining with ruthenium red with no mucilage. $\mathbf{h}$ Wax-like material on the surface of the epidermis (white arrow, Auramine O). i Epidermis and subepidermal secretory tissue of the groove, note the secretory material on the surface (black asterisk) (TBO). $\mathbf{j}$ Details of the groove epidermis with periplasmic spaces beneath the cuticle (black arrow) (TBO). e epidermis, $i$ idioblast, is intercellular spaces, $n$ nuclei, se subepidermal tissue, st starch, $v b$ vascular bundle

detect the presence of cuticle (Heslop-Harrison 1977), especially unsaturated acidic waxes and cutin precursors (Gahan 1984). Nucleus structure was examined in preparations stained with the fluorochrome 4',6-diamidino-2-phenylindole (DAPI). Staining reactions with Auramine O and DAPI were examined with a Nikon Eclipse E800 fluorescence microscope equipped with filter B-2A (EX 450-490 nm, DM $505 \mathrm{~nm}$, BA $520 \mathrm{~nm}$ ).

Following dehydration in an ethanol series, the samples were prepared and subjected to critical-point drying using liquid $\mathrm{CO}_{2}$, coated with gold and examined for micromorphological studies by scanning electron microscopy (SEM) using a Philips XL-30 at an accelerating voltage of $15-20 \mathrm{kV}$ (Laboratory of Electron Microscopy, University of Gdańsk, Poland).

To analyse ultrastructural features in transmission electron microscopy (TEM), labellum was fixed in $2.5 \%(v / v)$ glutaraldehyde (GA) in $0.05 \mathrm{M}$ cacodylate buffer $(\mathrm{pH} 7.0)$. The material was then post-fixed overnight in $1 \%(w / v) \mathrm{OsO}_{4}$ in cacodylate buffer in a refrigerator and finally rinsed in buffer. After $1 \mathrm{~h}$ in a $1 \%(w / v)$ aqueous solution of uranyl acetate, the material was dehydrated with acetone and embedded in Spurr's resin (Spurr 1969). Semi-thin sections $(0.8-1 \mu \mathrm{m}$ thick) were mounted on glass slides and treated with a $0.3 \%$ $(w / v)$ ethanolic solution of Sudan Black B (SBB, C.I. 26150) for lipid localization (Bronner 1975), observed with a Nikon Eclipse E800 light microscope. Ultrathin sections were cut on a Leica EM UC7 ultramicrotome with a diamond knife and stained with uranyl acetate and lead citrate (Reynolds 1963). Samples were prepared for the above mentioned observations in accordance with previously described procedures (i.e. Kowalkowska et al. 2010; Krawczyk et al. 2016; Święczkowska and Kowalkowska 2015; Naczk et al. 2018). The sections were examined in a Tecnai G2 Spirit BioTwin FEI transmission electron microscope (Laboratory of Electron Microscopy, University of Gdańsk, Poland) at an accelerating voltage of $120 \mathrm{kV}$.

To identify the chemical composition of lips, they were extracted in $20 \mathrm{ml}$ of dichloromethane and methanol (separately) for $15 \mathrm{~min}$. The extracts were filtered and collected in a glass vial. Solvents were evaporated under nitrogen to $4 \mathrm{ml}$ at room temperature and extracts were kept at $4{ }^{\circ} \mathrm{C}$ until analysed. Sugars were identified as native compounds and as trimethylsilyl derivatives (TMSi). Silylized derivatives were obtained by the addition of $0.1 \mathrm{ml}$ BSTFA + TMCS (99:1; Sigma Aldrich) to $1 \mathrm{mg}$ of each extract, and left for $1 \mathrm{~h}$ at $100{ }^{\circ} \mathrm{C}$ (Evershed 1992; Christie 1994). The samples were analysed by gas chromatography/mass spectrometry on a GC/MS QP-2010 SE (Simadzu, Kyoto, Japan) equipped with a fused silica capillary column ZB-5, $30 \mathrm{~m} \times 0.25 \mathrm{~mm}$ i.d., and with a film $0.25 \mu \mathrm{m}$ thick. Helium was used as the carrier gas at a flow rate of $1 \mathrm{ml} \mathrm{min}^{-1}$. Electron impact mode was performed at $70 \mathrm{eV}$. The injector and GC-MS interface temperatures were held at $310^{\circ} \mathrm{C}$. The ion source was maintained at $200^{\circ} \mathrm{C}$. The split ratio was $1: 20$, and the injection volume was $1 \mu \mathrm{L}$. The column temperature was programmed from 40 to $310{ }^{\circ} \mathrm{C}$ at $4{ }^{\circ} \mathrm{C} \mathrm{min}{ }^{-1}$ and then held at $310{ }^{\circ} \mathrm{C}$ for $10 \mathrm{~min}$. Organic compounds were identified on the basis of characteristic silyl derivative ions or on the basis of the mass spectra obtained for native compounds. The relative composition of the fraction was determined based on the peak areas from the total ion current (TIC).

\section{Results}

Living flowers of B. echinolabium (Fig. 1a) were approximately $25 \mathrm{~cm}$ long with glistening, yellowish with lilac-pink nerves tepals (Fig. 1a, b), a pale yellow column with dark purple stelidia and a yellow with purple anther-cap (Fig. 1b, c). In the labellum, attached to the base of the floral column by a small, springy hinge, two macromorphologically different areas were distinguished: the reddish hypochile and the yellowish, canaliculate epichile (Fig. 1b). The fleshy and echinate hypochile had a brighter groove between keels (Fig. 1b, c). The prickles (according to Wood 2005) were multicellular outgrowths (Figs. 1d, e and 2c), covered with fragmented cuticle (Fig. 1f, g, compare with Fig. 5a, c, d). In contrast, the adaxial surface of epichile was built by smooth cells, rectangular in shape, and without any cuticle striations or residues on the outer surface (Fig. 1h). Likewise, epidermal cells of stelidia were polygonal and smooth on the inner surface (Fig. 1i) and elongated and with slight cuticular striations on the appendage (Fig. 1j), which did not indicate secretion.

There were no significant differences at a histochemical level between particular parts (groove and prickles of hypochile, apical and basal parts of epichile), therefore they will be described in general way as hypochile and epichile. In the transverse section, the adaxial part of both hypochile and epichile contained a single-layered epidermis, few layers of subepidermal cells and a deeply located ground parenchyma consisting of larger, more vacuolated cells, through which 

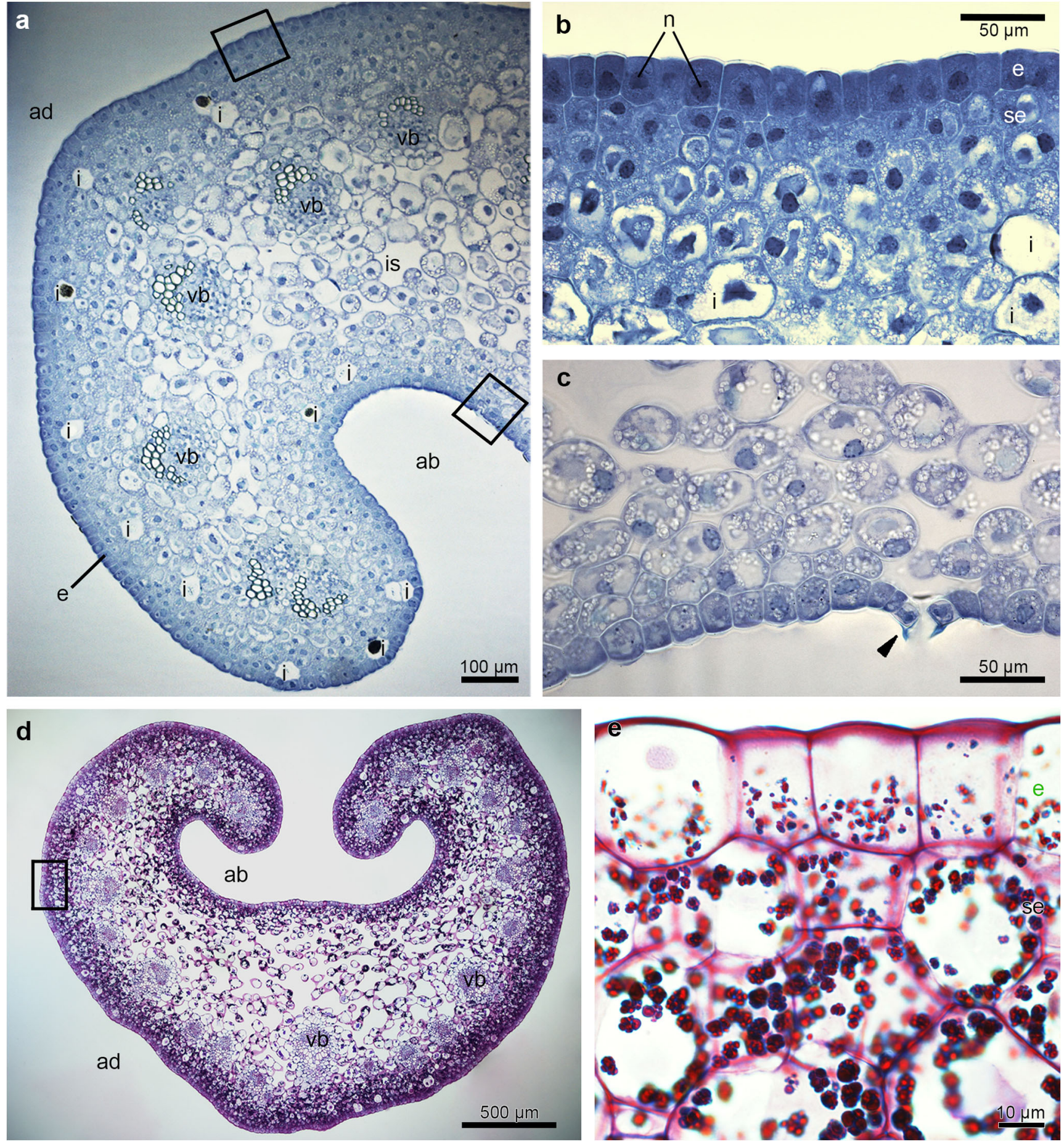

Fig. 3 Histochemical features of the B. echinolabium epichile (transverse sections). a General view showing a single layer of epidermis, a few layers of subepidermal cells with idioblasts and several collateral vascular bundles in the ground parenchyma (TBO). b Detail of transverse section (a) (square) epidermis with dense cytoplasm and enlarged nuclei stained intensively for proteins (ABB). c Detail of a (square), abaxial surface of the epichile with stoma (arrowhead, TBO). d Transverse section of the epichile tissue (PAS). e Details of $\mathbf{d}$ (square), abundance of starch grains in subepidermal tissue. $a b$ abaxial surface, $a d$ adaxial surface, $e$ epidermis, $i$ idioblast, $i s$ intercellular spaces, $n$ nuclei, $s e$ subepidermal tissue, $v b$ vascular bundle

layers of cells containing dense parietal cytoplasm with enlarged nuclei (stained with DAPI, Figs. 2b, 4b). In both prickles and the groove, the secretory material was noted on the surface (Fig. 2e, i). Only the epidermal cells of the groove 

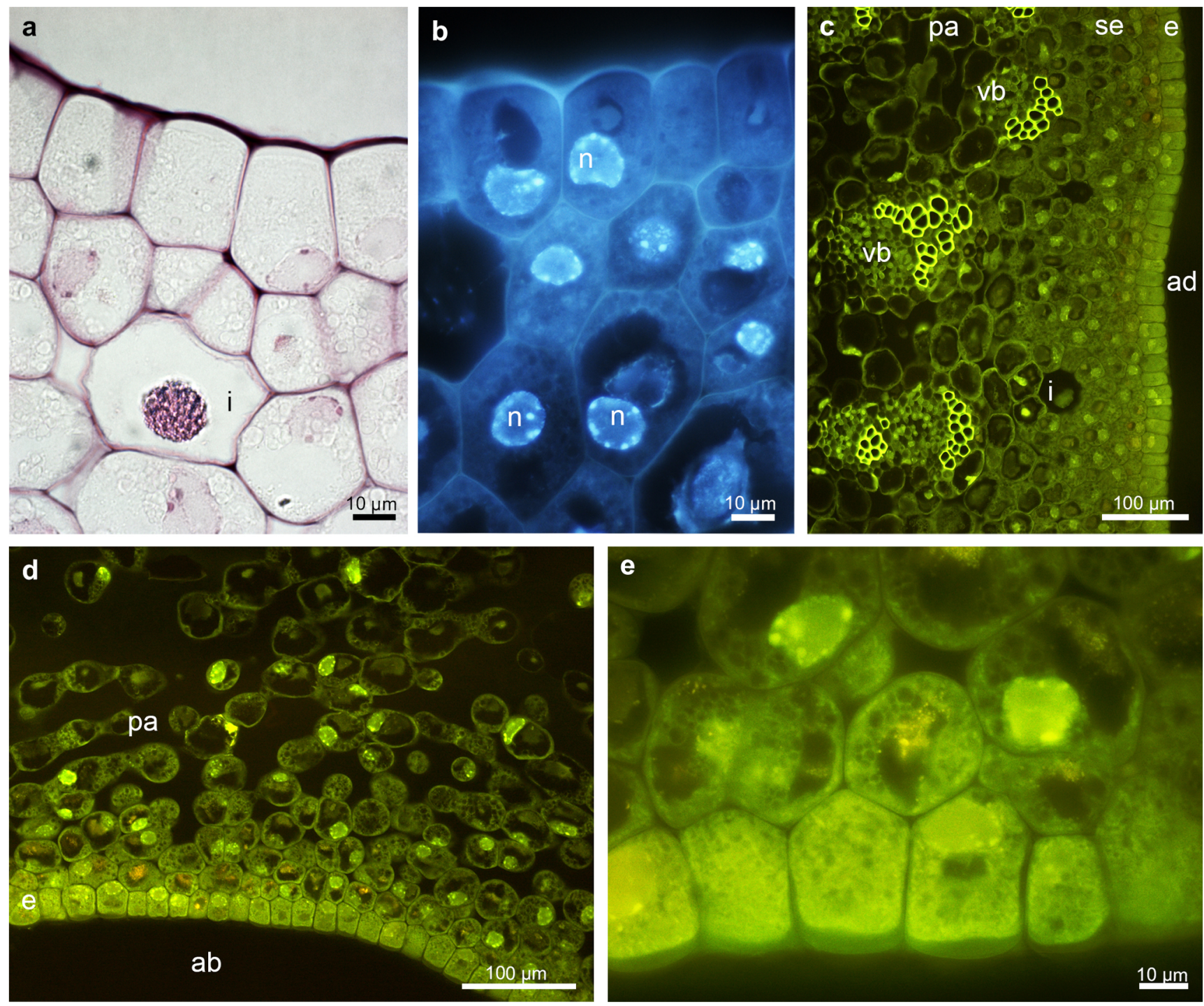

Fig. 4 Histochemical features of the middle part of the epichile of B. echinolabium. a Transverse section: the epidermis and few layers of subepidermal cells with idioblasts following staining with ruthenium red. b The epidermis and subepidermal tissue with enlarged, nuclei (DAPI). c,

exhibited periplasmic spaces beneath the cuticle (Fig. 2j). Histochemical results also showed a great number of similarities between the tissue of hypochile and epichile. An abundance of proteins was observed in the adaxial epidermis and subepidermal tissue, although there was a distinctly greater amount in the epichile (Figs. 2e and 3b). The stomata were present on the abaxial surface of the epichile (Fig. 3c). Starch occurred throughout the labellum, but was most profusely found in adaxial subepidermal tissue of both hypochile (Fig. 2c, d) and epichile (Fig. 3d, e). Single lipid droplets were detected mostly in the epidermis and subepidermal cells (Fig. 2f). Additionally, the test with ruthenium red did not reveal the presence of mucilage neither in hypochile (Fig. 2g) or epichile (Fig. 4a). The unsaturated acidic waxes were detected in the cuticle (Auramine O, Figs. $2 \mathrm{~h}$ and $4 \mathrm{c}-\mathrm{e}$ ).

d Transverse sections of adaxial (inner) and abaxial (outer) surfaces stained with Auramine O. e Detail of d. $a b$ abaxial surface, $a d$ adaxial surface, $e$ epidermis, $i$ idioblast, $n$ nuclei, $p a$ parenchyma, $v b$ vascular bundle

The TEM studies have been made on groove (Fig. 5) and prickles (Figs. 6, 7 and 8a, b) (hypochile) and adaxial part of the epichile (Figs. 8c, d and 9). The TEM examination revealed no secretory material on the epidermal cells of groove (Fig. 5a, b) in contrast to large amounts of heterogeneous, possibly phenolic residues of secreted material on the cuticle surface of the prickle cells (Figs. 6a, b, d, f and 7a, b, d). Likewise, in the adaxial surface of the epichile, epidermal cells with small amounts of secretory material were noted (Fig. 9a, b, d). Micro-channels in cuticle occurred only in the groove cells (Fig. 5a, b). The large, prominent periplasmic space with flocculated secretory material and numerous vesicles (Figs. 5a, c, 6a-c, 7a-c, 8c, d and 9b-d) appeared in the epidermal cells of whole labellum. A noteworthy feature, observed in both hypochile and epichile, was the presence of 

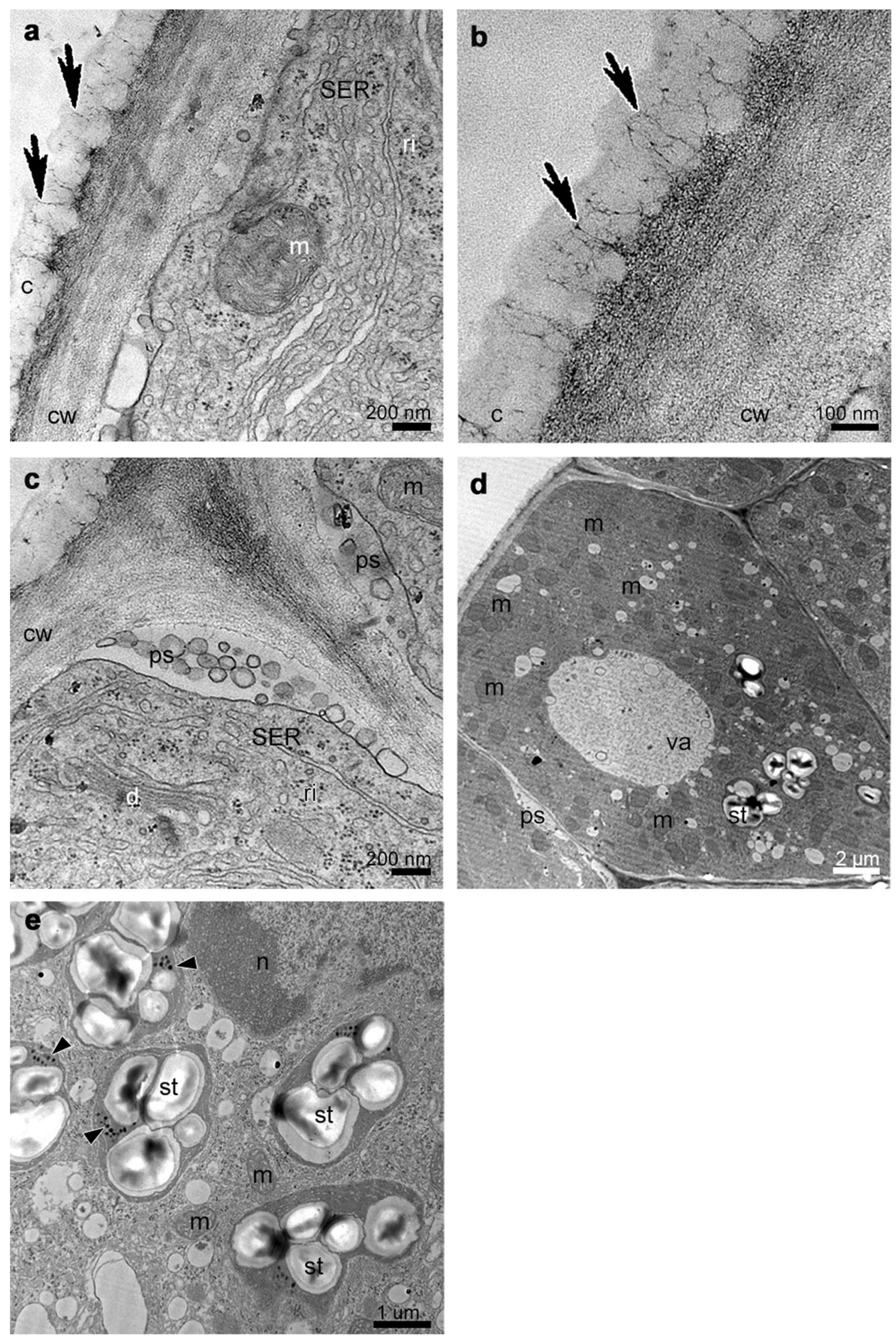
Fig. 5 Ultrastructural analysis (TEM) of the groove of the hypochile showing secretory epidermal cells with heterogeneous cell wall and micro-channels in cuticle (black arrows, a, b), periplasmic space with flocculated secretory material and numerous vesicles building into plasmalemma (a, c), profiles of SER (a, c), fully developed dictyosomes (c), mitochondria (d), ribosomes (d), plastids with starch grains $(\mathbf{d}, \mathbf{e})$ and plastoglobuli (black arrowheads, e). $c$ cuticle, $c w$ cell wall, $d$ dictyosome, $m$ mitochondrion, $n$ nucleus, $p s$ periplasmic space, $r i$ ribosomes, $s t$ starch grains, $v a$ vacuole

vesicles building into the plasmalemma in the epidermis and subepidermal cells (Figs. 5a, 6a and 9a), occasionally with electron dense (possibly phenolic) substances within (Fig. 6e). The dense cytoplasm of the epidermis and subepidermal tissue contained enlarged nuclei (Figs. 5a, 8c and 9a), numerous mitochondria (occasionally in degenerative stage) (Figs. 5d, e, 7a, c, d, 8a, c, d and 9a-e), the profiles of SER and RER and fully developed dictyosomes (Figs. 5a, c, 7a-c, 8b and $9 \mathrm{a}, \mathrm{c}-\mathrm{e})$. Lipid droplets occurred in the prickles and epichile (Figs. 7d and 9d). Additionally, an abundance of plastids, including chromoplasts with plastoglobuli (Figs. 5d, 8b and 9e) and amyloplasts with starch grains, and tubules (Figs. 5d, e, 7b, 8a-d and 9d) were present. Numerous plasmodesmata connected adjacent epidermal cells (Fig. 9e).

All these results are summarized and compared with those of previously published species from the section Lepidorhiza in Table 1.

Living flowers emitted a strong, unpleasant smell of rotten waste. The analysis of the volatile fraction revealed the presence of a number of compounds (Table 2), mainly Diptera attractants (glycerol 1-palmitate, hexadecane, tridecane, decanal, nonanal, undecane, beta.-Linalool, limonene, 2Hexenal, Cholest-5-en-3-ol), but also pheromones, allomones and kairomones of other insects (Hymenoptera, Heteroptera, Coleoptera, Lepidoptera) and some Carnivora. GC/MS analysis revealed that the methanol extract of lip tissue (Table 3) comprised mainly of $29.55 \%$ of different carbohydrates and their derivatives (mono- and polysaccharides, sugar alcohols, sugar acids). The main organic compound was cyanuric acid $(23.61 \%)$, which is also obtained by urea decomposition.

\section{Discussion}

Secretory activity was observed on the hypochile (on the longitudinal groove, keel and on the prickles) and the epichile of Bulbophyllum echinolabium. Considering the presence of carbohydrates (29.55\% in GC/MS), the profusion of starch grains (PAS) and a large amount of the secretory material on hypochile (TEM), we consider it nectar. Nectar is mainly composed of monosaccharides (glucose and fructose) and a disaccharide (sucrose), with different concentrations among species (Percival 1965). The proportion of monosaccharides over disaccharides confirms that this hexose-rich nectar is offered for flies and was also identified in flowers pollinated by shorttongued bees, bats and perching birds (Baker and Baker 1983, 1990; Lammers and Freeman 1986; Elisens and Freeman 1988; Stiles and Freeman 1993; Baker et al. 1998; apud Perret et al. 2001). Whereas, the epichile, with cells histochemically and ultrastructurally the same as the hypochile, but with slight accumulation of exuded material on the surface, functions as a putative osmophore.

The typical histological organization, in both the hypochile and epichile of the species here studied, was distinguished as a single-layered epidermis with several layers of subepidermal parenchyma and mesophyll-like ground parenchyma with collateral vascular bundles. Such regions were previously described in species from section Lepidorhiza (Wiśniewska et al. 2018), Neotropical sections Didactyle (Nunes et al. 2014), Napelli (Nunes et al. 2015), Racemosae (Davies and Stpiczyńska 2014; Stpiczyńska and Davies 2016), African (Teixeira et al. 2004; Stpiczyńska et al. 2015) and Asian representatives of the genus (Kowalkowska et al. 2015a, 2017). Alike in other Lepidorhiza species, in B. echinolabium, the exudate could pass diffusely through the cuticle or accumulate under the cuticle and, as a result of increasing pressure, could emerge outside the cells through cuticular cracks. The prominent periplasmic space appeared in the epidermal cells of both the hypochile and epichile. Interestingly, subcuticular spaces were present in two other species from the section Lepidorhiza (Wiśniewska et al. 2018). The formation of periplasmic spaces is probably connected with merocrine secretion, where glands or cells remain alive after secretion and continue their secretory activity. Generally, our observations of B. echinolabium support the hypothesis proposed by Paiva (2016), where synthesized substances are transported via vesicles to the periplasmic space (granulocrine secretion), from which they are transported out through the cuticle as a result of increasing pressure. The presence of the irregular plasmalemma, secretory vesicles fusing with it and fully developed dictyosomes also indicates granulocrine secretion, as reported previously in orchids (i.e. Kowalkowska et al. 2012, 2015b; Wiśniewska et al. 2018). Moreover, the enlarged nucleus, as well as the abundance of mitochondria, indicate high cellular activity. In the labellum of B. echinolabium, a large number of idioblasts contained raphides of calcium oxalate crystals, which play a significant role in deterring herbivores. Idioblasts located close to the secretory tissue in tepals are a common feature and are frequently noted (i.e. Kowalkowska et al. 2015b; Wiśniewska et al. 2018).

A great number of compounds identified in the whole lip are Diptera attractants. Fifteen out of 43 volatile compounds found in B. echinolabium are described in the Pherobase (ElSayed 2019) as semiochemicals (attractants, pheromones, allomones or kairomones). Most of them specifically attract Diptera (mostly Milichiidae, Muscidae, Drosophilidae, Sarcophagidae, Chloropidae, Tephritidae and Tachinidae). 

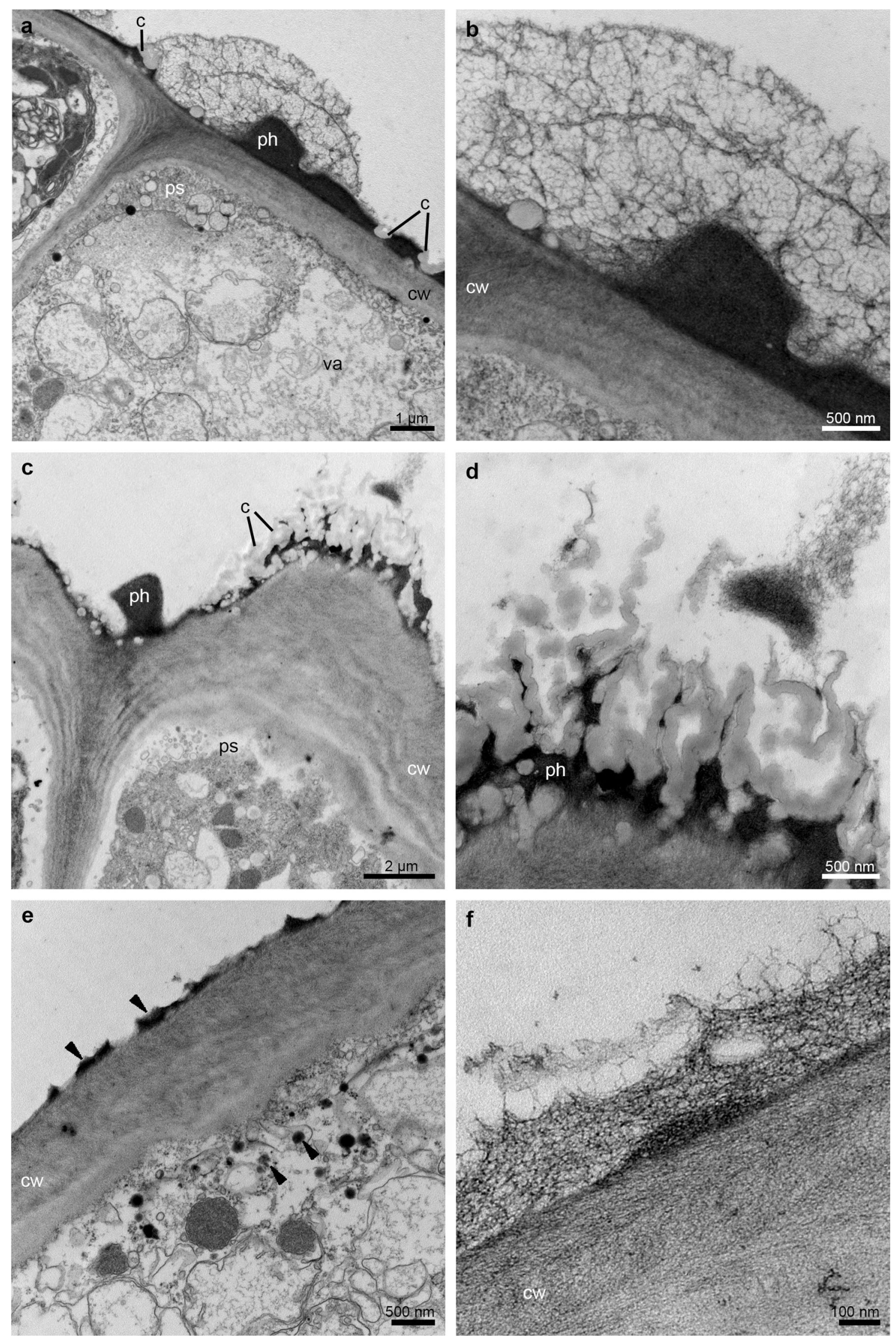
Fig. 6 Ultrastructural analysis (TEM) of the appendix of the prickle in the middle part of the hypochile. a Sections through the epidermal cell wall with periplasmic spaces beneath and large amounts of heterogeneous residues of secreted material with fragmented pieces of the cuticle on the surface. b Detail of a. c Phenolic secretory material on the cuticle surface and periplasmic spaces beneath the cell wall. d Detail of c. e Phenolic material on the cuticle surface (black arrowheads) and inside the numerous vesicles fusing with the plasmalemma. $\mathbf{f}$ Detail of the epidermis cell wall with secretory material on the surface. $c$ cuticle, $c w$ cell wall, $p h$ phenolic secretion, $p s$ periplasmic space, $v a$ vacuole

Semiochemicals are natural chemicals released by organisms and used as a main channel of communication. The signals, intraspecific or interspecific, are used in many behavioural
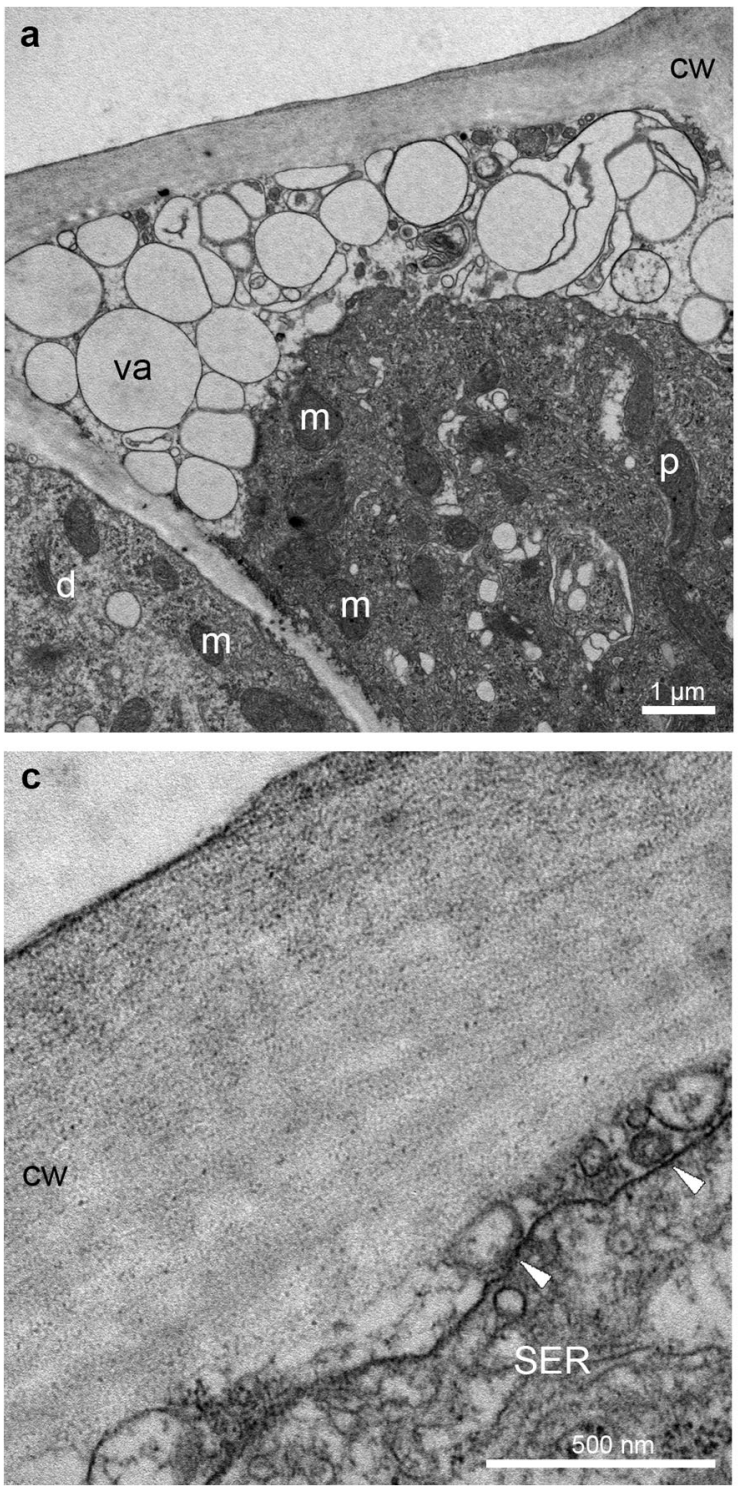

Fig. 7 Ultrastructural details (TEM) of the prickle (hypochile) showing secretory epidermal cells with dense cytoplasm, numerous small vacuoles in close vicinity of the cell wall $(\mathbf{a}, \mathbf{b})$, an abundance of mitochondria, plastids with starch grains and plastoglobuli $(\mathbf{a}, \mathbf{b}, \mathbf{d})$, fully developed dictyosomes (a, b), profiles of smooth (SER) and rough endoplasmic functions, including sexual attraction, aggregation, trail following, recruitment, defence or host location (El-Sayed 2019). Furthermore, two other semiochemicals might also attract flies floral odours - 3-ethyl-2-methyl-1-heptene and 3,7dimethyl-2-octene are also detected in the faeces and the body odour composition of ox, respectively (Gikonyo et al. 2002; Wishart et al. 2018). Limonene, in turn, was noted in small amounts in Ferraria crispa (Johnson and Jürgens 2010), as well as in horse dung, where it was a dominant compound (39\%). Terpinen-4-ol occurs in many species of Orchidaceae (263 species described in the Pherobase) and likewise in two fly-pollinated species from Araceae: Arum maculatum and Sauromatum guttatum (El-Sayed 2019).
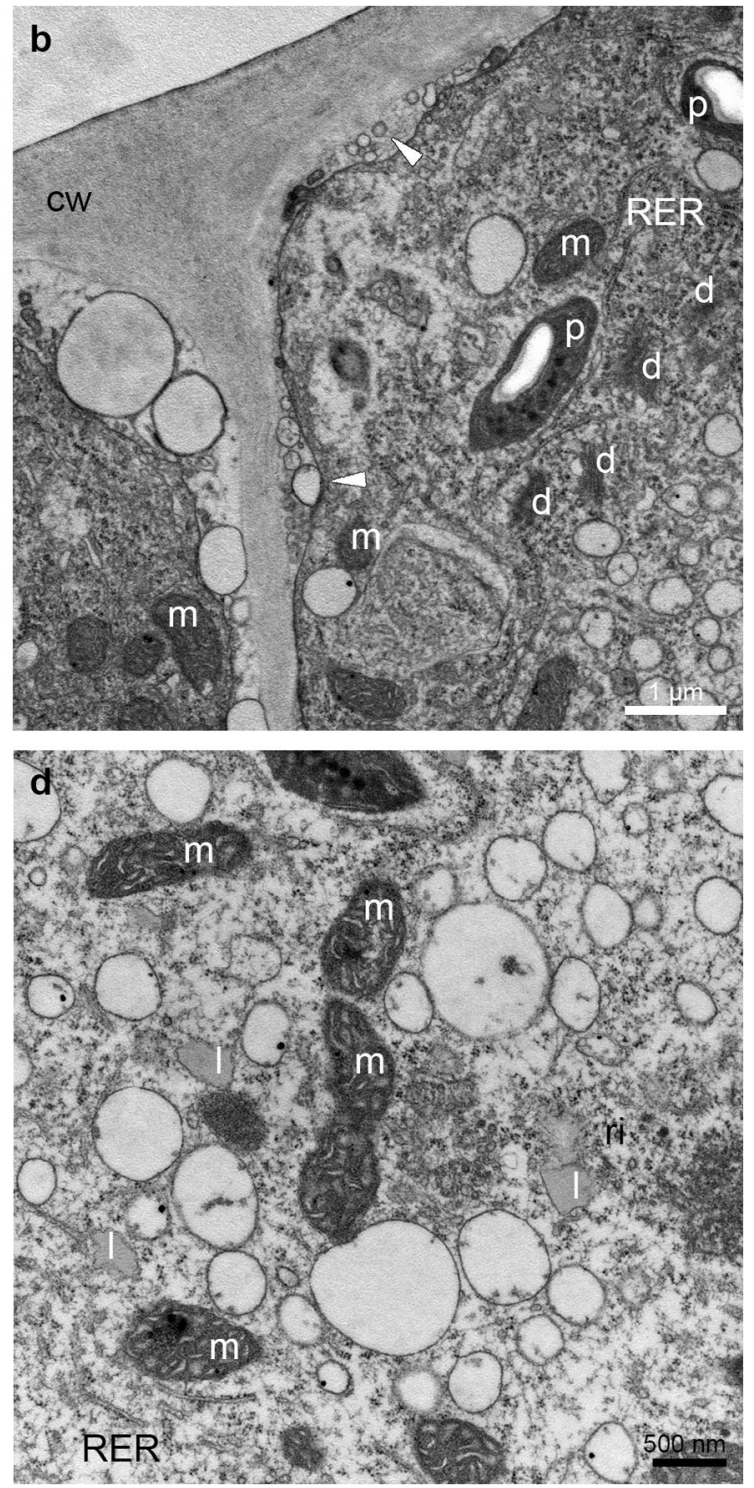

reticulum (RER) (b-d), lipid droplets (d) and periplasmic space with flocculated secretory material and numerous vesicles building into plasmalemma (white arrowheads) (b, c). $c w$ cell wall, $d$ dictyosome, $l$ lipid droplet, $m$ mitochondrion, $p$ plastid, $p s$ periplasmic space, $v a$ vacuole 

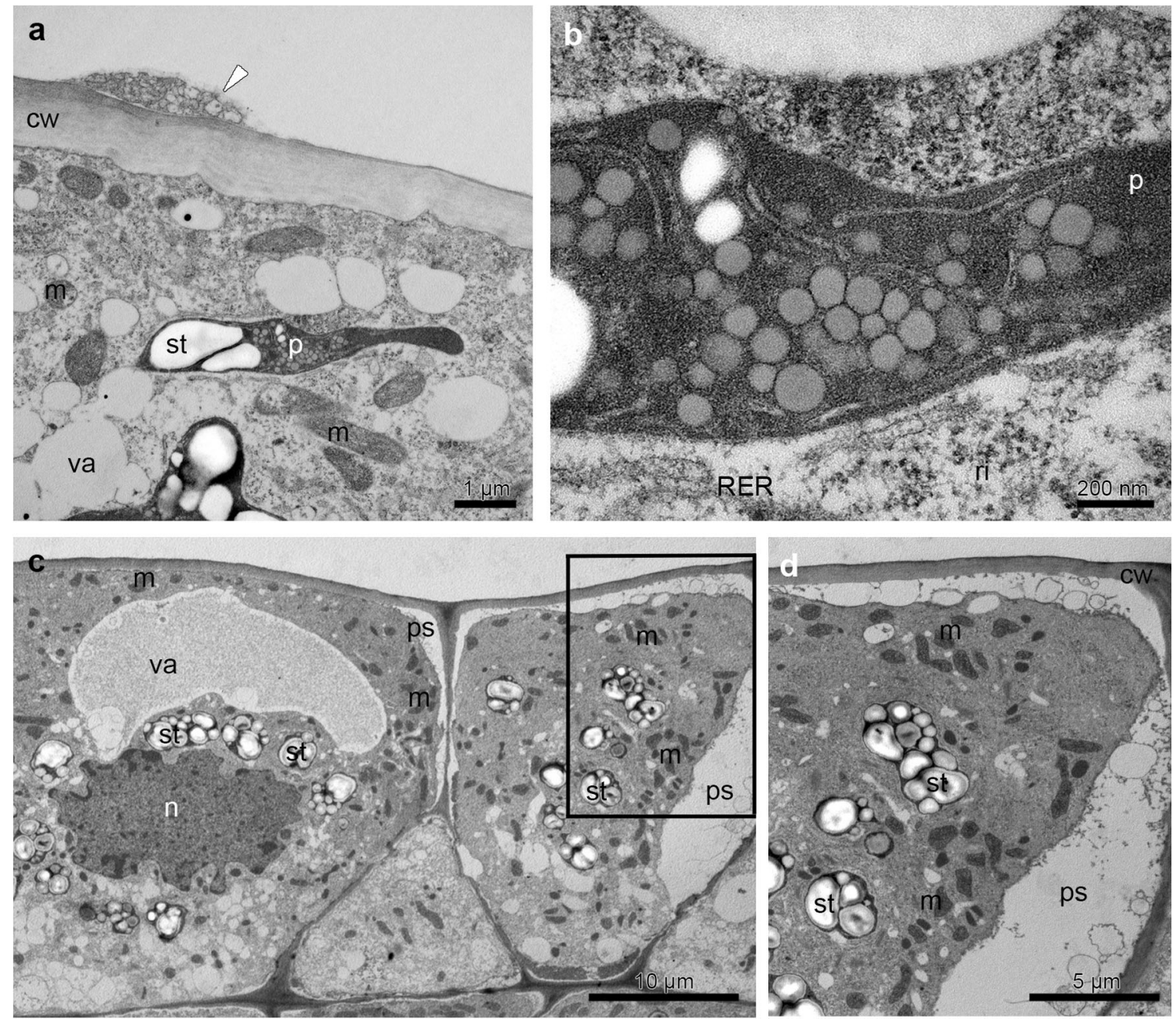

Fig. 8 Ultrastructural analysis (TEM) of the prickles on the hypochile (a, b) and basal part of the epichile $(\mathbf{c}, \mathbf{d})$ revealed a residues of secretory material on the cuticle surface (white arrowhead), plastids with plastoglobuli, tubules and starch grains (a-d) and profiles of SER and RER (b), numerous mitochondria (a-d). c Epidermal cells containing a prominent periplasmic space with flocculent material (c, $\mathbf{d}, \mathbf{d}$ detail of $\mathbf{c})$, dense cytoplasm with enlarged nuclei (c). $c w$ cell wall, $d$ dictyosome, $m$ mitochondrion, $n$ nuclei, $p$ plastid, $p s$ periplasmic space, $r i$ ribosomes, $s t$ starch grains, $v a$ vacuole

of sapromyophilous species, e.g. Caralluma europea (Formisano et al. 2009), Duvalia corderoyi, Hoodia gordonii, Orbea variegata (Jürgens et al. 2006), Stapelia leendertziae, O. verrucosa, Euphorbia grandicornis (Johnson and Jürgens 2010), as well as in several types of decaying organic matter, such as dog (Arnould et al. 1998), rabbit (Goodrich et al. 1981) and cow faeces (Kite 1995). The electron dense secretion residues on and beneath the cuticle surface and in plastoglobuli in plastids are possibly phenolic in nature. In B. echinolabium, ER profiles were closely associated with plastids containing plastoglobuli, as well as numerous vesicles with electron dense material, fusing with plasmalemma. The volatile (phenolic) components of fragrances are synthesized in plastoglobuli: hence, they are transported to the intraplastidal membranes, crossing the plastid envelope to the profiles of ER (or migrating independently in cytoplasm) 

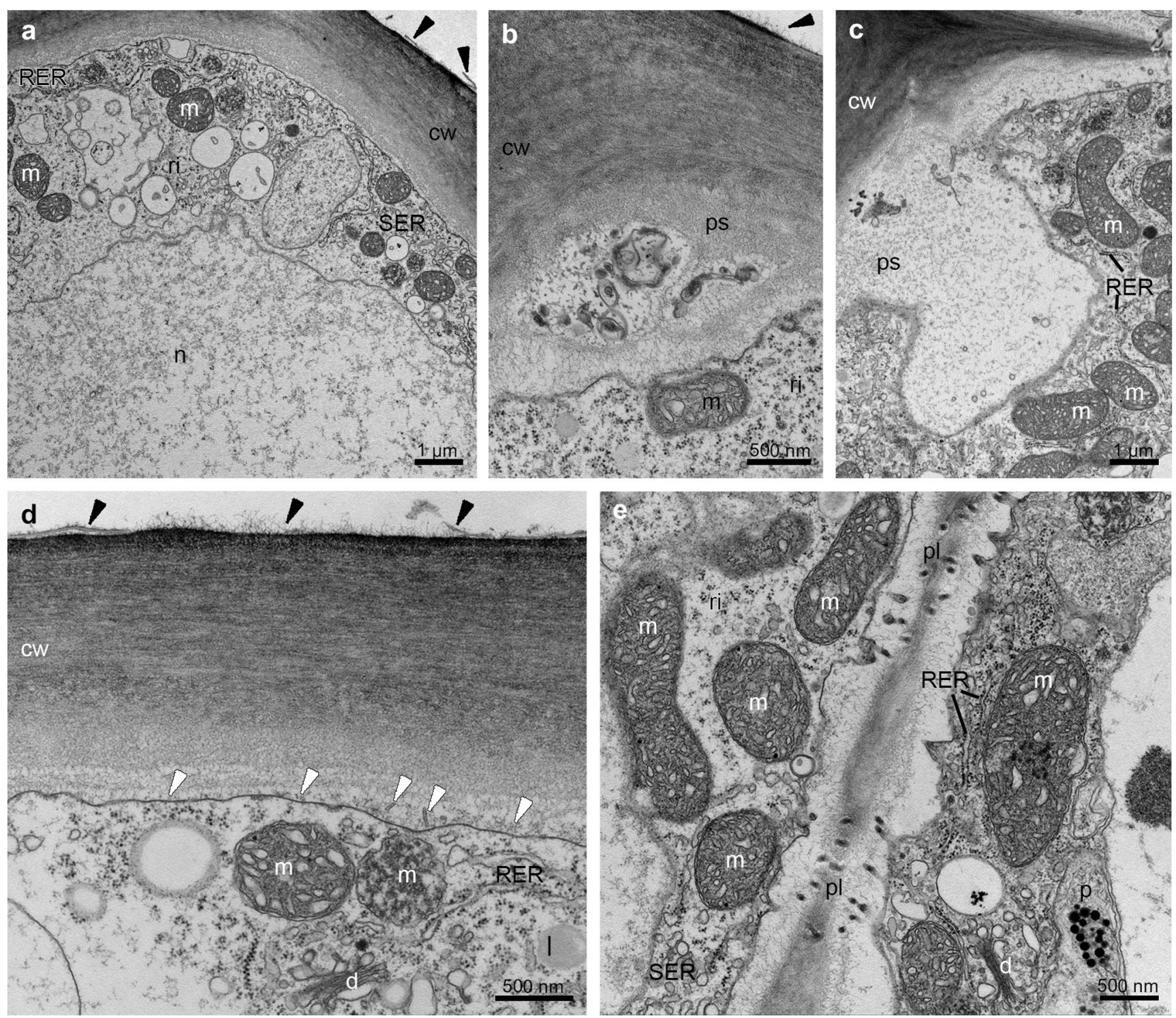

Fig. 9 Ultrastructural details (TEM) of the adaxial surface of the middle part of the epichile revealed epidermal cells with secretory material (black arrowheads $)(\mathbf{a}, \mathbf{b}, \mathbf{d})$, dense cytoplasm with numerous mitochondria (ae), prominent periplasmic space with flocculent material (b, c), abundant SER and RER (c-e), fully developed dictyosomes (d, e), plasmalemma with irregular outline and vesicles building into it (white arrowheads) (d),

and finally to the plasmalemma, where they exit the cells. Plastid involvement in the synthesis of fragrance components has been described previously (Stern et al. 1987; Kowalkowska et al. 2012; Stpiczyńska and Davies 2016) and in other Lepidorhiza representatives (Wiśniewska et al. 2018).

Cuticular striations covered with epicuticular wax layers (stained with Auramine O) present on the B. echinolabium labellum adaxial surface could cause the brilliance of floral tepals as well as shining nectar. Meve and Liede (1994) called it "mimetic surface reflexion", where glistering plasmodesmata connecting adjacent epidermal cells (e) and secretory material on surface (d), lipid bodies (d), plastids-chromoplasts with plastoglobuli (e). $c w$ cell wall, $d$ dictyosome, $l$ lipid bodies, $m$ mitochondrion, $n$ nuclei, $p$ plastid, $p l$ plasmodesmata, $p s$ periplasmic space, $r i$ ribosomes

surfaces strongly attract flies by imitating open flesh wounds or fresh dung surfaces. Furthermore, residues might function as a visitor guide to align the mouth parts of the flies to achieve successful pollinaria transfer (Endress 1994; Meve and Liede 1994; Jürgens et al. 2006). Carnivorous plants from the genus Nepenthes are covered with a thick layer of epicuticular wax, forming slippery zones for pollinators, which seem to play a crucial role in animal trapping. Tepal striations are considered to intensify floral attraction for pollinators (in Bulbophyllum-Nunes et al. 2015). Furthermore, 
Table 1 A comparison of macromorphology, anatomy, micromorphology, and ultrastructure of labellum of $B$. levanae and B. nymphopolitanum (Wiśniewska et al. 2018) and the examined
B. echinolabium (for the need of this presentation, hypochile and epichile are presented together). + present, - absent

\begin{tabular}{llll}
\hline Species/method & $\begin{array}{l}\text { B. levanae } \\
\text { (Wiśniewska et al. 2018) }\end{array}$ & $\begin{array}{l}\text { B. nymphopolitanum } \\
\text { (Wiśniewska et al. 2018) }\end{array}$ & $\begin{array}{l}\text { B. echinolabium } \\
\text { Lip }\end{array}$ \\
& Lip & & \\
Lip (hypochile and epichile)
\end{tabular}

Table 2 Chemical composition of labellum (hypochile and epichile together) of Bulbophyllum echinolabium J.J. Sm. (GC/MS analysis, extract from dichloromethane) in the context of its impact on Diptera

Dichloromethane $\quad \% \quad$ Properties and occurrence (based on El-Sayed 2019)

\section{Diptera attractants}

Cholest-5-en-3-ol

Glycerol 1-palmitate (hexadecanoic acid)

Hexadecane

Tridecane

Decanal

Nonanal

Undecane

beta-Linalool
5.9 Pheromone Lucilia sericata (Calliphoridae), Hymenoptera, Lepidoptera and Vertebrata (i.a. Bufonidae, Colubridae, Pythonidae, Iguanidae)

4.97 Attractant Diptera, Coleoptera, Homoptera and Astigmata; pheromone, allomone and kairomone Coleoptera, Diptera, Ixodida, Lepidoptera and some Carnivora; noted in numerous Araceae (Sauromatum guttatum, Spathiphyllum cannaefolium,

S. floribundum) and Orchidaceae (Bulbophyllum involutum, B. ipanemense, B. weddellii);

present in human odour (Curran et al. 2005)

3.17 Anti-inflammatory, beta-oxidant and thermogenic functions; attractant Diptera (Tephritidae and Sciaridae), pheromone Hymenoptera and Coleoptera; found in many Orchidaceae (i.a. Aerangis spp., Cattleya spp., Dendrobium spp., Odontoglossum spp., Oprhys spp.), Cactaceae, Araceae

2.16 Attractant Diptera (Chloropidae and Milichiidae), pheromone and allomone Hymenoptera, Heteroptera, Coleoptera; found mainly in Araceae, Arecaceae, Orchidaceae (Coryanthes spp., Cymbidium spp., Ophrys spp., Phalaenopsis spp.), Magnoliaceae, Moraceae

1.85 Attractant, allomone and kairomone Diptera (Muscidae, Tephritidae and Ceratopogonidae), Coleoptera, Lepidoptera; found in many Araceae, Orchidaceae (i.a. Aerangis spp., Catasetum spp., Cirrhopetalum spp., Coryanthes spp., Dendrobium spp., Gongora spp., Stanhopea spp.), Cactaceae, Caryophyllaceae, Rosaceae

1.48 Attractant Coleoptera, several Diptera (Tephritidae, Muscidae, Culicidae); found in Araceae, Arecaceae, Orchidaceae (i.a. Aerangis spp., Catasetum spp., Coryanthes spp., Dendrobium spp., Gongora spp., Masdevallia spp., Ophrys spp.), Cactaceae, Caryophyllaceae, Clusiaceae

1.47 Attractant Diptera (Chloropidae, Milichiidae and Muscidae); allomone and pheromone Hymenoptera and Coleoptera found mainly in Araceae, Arecaceae, Orchidaceae (i.e. Oprhys spp., Stanhopea spp.), Rosaceae, Hypericaceae

1.31 Attractant, allomone, pheromone and kairomone Diptera (Anthomyiidae, Drosophilidae, Muscidae, Sarcophagidae, Scatopsidae, Tachinidae), Hymenoptera, Coleoptera and Lepidoptera; found mainly in Apocynaceae, Araceae, Apiaceae, Arecaceae, Brassicaceae, Orchidaceae (i.a. Aerangis spp., Brassavola spp., Catasetum spp., Coryanthes spp., Dendrobium spp., Dracula spp., Gongora spp., Masdevallia spp., Maxillaria spp., Oprhys spp., Stanhopea spp.), Cactaceae, Caryophyllaceae, Nyctaginaceae, Fabaceae, Magnoliaceae 
Table 2 (continued)

Dichloromethane

Limonene

2-Hexenal
$\% \quad$ Properties and occurrence (based on El-Sayed 2019)

1.18 Attractant Diptera (Milichiidae, Tephritidae, Chloropidae and Dolichopodidae); Dominant compound (39\%) in horse dung odour (Johnson and Jurgens 2010) occurs in other Orchidaceae (i.a. Cattleya spp., Coryanthes spp., Dendrobium spp., Oprhys spp., Stanhopea spp.)

0.56 Attractant Diptera (Milichiidae, Chloropidae and Tachinidae, Tephritidae, Phoridae, Psilidae); found mainly in Cactaceae, Fabaceae, Lauraceae, Cupressaceae

Pheromones, allomones and kairomones of other insects (Coleoptera, Hymenoptera, Lepidoptera), arachnids (Astigmata) and Vertebrata (Canidae, Iguanidae)

Cholest-4-en-3-one

Hexadecen-1-ol, trans-9-

Dodecanoic acid, 1-methylethyl ester

Tetradecane

Dodecane
6.08 Pheromone Vertebrata (Canidae, Iguanidea)

4.13 Pheromone Lepidoptera and Hymenoptera (Bombus sp.)

3.08 Allomone and pheromone Coleoptera, pheromone Hymenoptera

2.46 Pheromone and allomone Hymenoptera, Heteroptera, Coleoptera, Astigmata

1.83 Pheromone and allomone Hymenoptera, Coleoptera; found in Araceae and Orchidaceae

Properties and occurrence of other constituents (in context of fly pollination or medical significance)

Tridecanol, 2-ethyl-2-methyl-

Benzenepropanoic acid, 3,5-bis(1,1-dimethylethyl)

-4-hydroxy-, methyl ester (Metilox)

7,9-Di-tert-butyl-1-oxaspiro(4,5)deca-6,9-diene-2,

8-dione

Isopropyl 12-methyl-tridecanoate

2,3,5,6-Detetrahydrocyclohexanone,

2,6-di-t-butyl-4-hydroxymethylene-

Octylacetophenone

Heptadecane, 4-methyl-

Benzoic acid, 3-ethyloxy-, ethyl ester

Phenol, 3,5-di-tert-butyl-

2,5-di-tert-Butyl-1,4-benzoquinone

Butoxyethoxyethyl acetate (2-(2-Butoxyethoxy) ethyl acetate)

Decane, 2,3,5,8-tetramethyl-

Dodecane, 2,6,10-trimethyl-

Dodecane, 2,6,11-trimethyl-

2-Octene, 3,7-dimethyl-

Undecane, 4-methyl-

2,6-Dimethyldecane

1-Heptanol, 2-propyl-

Santolina triene

2-Hexanol, 1-mercapto

3-Octen-5-yne, 2,7-dimethyl-

Cyclohexane, 1-methyl-3-propyl-

1-Butanol, 2-ethyl-

Cyclohexane, 1-methyl-3-propyl-

3-Ethyl-2-methyl-1-heptene
5.56 Noted in Acalypha wilkesiana (Euphorbiaceae) leaves, may be useful in the management of risk factors of cardiovascular diseases (Omage et al. 2018)

3.83 According to OECD (2001), SIAM 13, 6-9.11.2001 this chemical has no concern for health and for environment, currently of low priority for further work

, 3.79 Found in essential oils from Cordia sebestena (Boraginaceae) (Adeosun et al. 2013)

$3.56-$

$3.43-$

$3.09-$

$2.91-$

$2.81-$

2.78 Phenol derivative, found in essential oils of Azadirachta indica, Azadirachta siamensis and Azadirachta excelsa (Meliaceae) (Kurose and Yatagai 2005)

2.65 Neurotoxic for humans (O'Donoghue 1985), antimicrobial activity against Bacillus cereus (Gopal et al. 2013)

2.36 May cause an allergic skin reaction and respiratory irritation in vertebrates

(European Chemicals Agency 2019)

$2.14-$

$2.12-$

$2.1-$

1.71 Can be found in faeces (Wishart et al. 2018)

$1.53-$

$1.48-$

$1.45-$

$1.42-$

$1.15-$

$1.13-$

$0.84-$

$0.76-$

$0.74-$

0.72 Noted in ox carcass (Gikonyo et al. 2002) substances contained in epicuticular waxes function as allomones, deterring oviposition and feeding by herbivores (Eigenbrode and Espelie 1995; Müller and Riederer 2005).
In conclusion, our studies indicate that, despite differences in size and colour, $B$. echinolabium and previously studied $B$. levanae and B. nymphopolitanum have many similarities. 
Table 3 Chemical composition of labellum (hypochile and epichile together) of Bulbophyllum echinolabium J.J. Sm. (extract from methanol)

Methanol $\% \quad$ Properties (based on El-Sayed 2019)

\section{Amino acids}

L-phenylalanine

Serine

Norleucine

L-threonine

\section{Saccharides}

alpha-D-Glucopyranoside

D-Turanose

Sucrose

D-Glucose

Hydroquinone-beta-d-glucopyranoside

D-Galactose

Glucopyranose

2,3,4-Trihydroxybutyric acid

Glycoside, alpha-methyl

Ribonic acid

D-Xylopyranose

D-(-)-Tagatofuranose

Inositol

D-Ribofuranose

Erythritol

D-(+)-Xylose

Myo-Inositol

Fructose

beta-1-Galactopyranoside, methyl 6-deoxy-

D-Gluconic acid

Levoglucosan

d-Mannose

2-Keto-d-gluconic acid

Ribitol

\section{Lipids}

Stigmasterol

Campesterol

Cholesterol

1-Monopalmitin

\section{Others}

Cyanuric acid

Malic acid

1-Cyclohexene-1-carboxylic acid, 3,4,5-hydroxy

11.76

Citric acid

alpha-Hydroxyglutaric acid

Mannonic acid, 1,4-lactone

Benzoic acid, 3-methoxy

beta-Hydroxy-beta-methylglutaric acid

1.20

0.59

0.50

0.42

$\begin{array}{ll}0.74 & \text { Amino acid } \\ 0.46 & \text { Amino acid; pheromone Hymenoptera } \\ 0.26 & \text { Amino acid } \\ 0.20 & \text { Amino acid }\end{array}$

$\begin{array}{ll}11.70 & \text { Monosaccharide } \\ 3.84 & \text { Disaccharide } \\ 3.27 & \text { Disaccharide } \\ 3.08 & \text { Monosaccharide } \\ 1.53 & \text { Monosaccharide } \\ 1.10 & \text { Monosaccharide } \\ 1.10 & \text { Monosaccharide } \\ 1.00 & \text { Sugar acid } \\ 0.70 & \text { Monosaccharide } \\ 0.43 & \text { Sugar acid; can primarily be found in faeces } \\ 0.27 & \text { Monosaccharide } \\ 0.26 & \text { Natural sweetener present in fruits, cacao and dairy products } \\ 0.17 & \text { Polyol (multiple/sugar alcohol) } \\ 0.16 & \text { Monosaccharide } \\ 0.16 & \text { Sugar alcohol (aliphatic) } \\ 0.13 & \text { Monosaccharide } \\ 0.13 & \text { Polyol (multiple/sugar alcohol) } \\ 0.12 & \text { Monosaccharide } \\ 0.09 & \text { Monosaccharide } \\ 0.08 & \text { Carboxylic acid formed by the oxidation of the first carbon of glucose } \\ 0.08 & \text { Anhydrohexose } \\ 0.07 & \text { Aldohexose } \\ 0.05 & \text { Carrageenan polysaccharide } \\ 0.03 & \text { Sugar alcohol } \\ & \\ \end{array}$

5.27 Phytosterol (lipid)

1.39 Phytosterol (lipid)

1.22 Sterol (lipid) - attractant of blow fly Lucillia sericata

0.16 Monoacylglycerols - minor component of olive oil and other vegetable oils
Obtained by urea decomposition, which is final product in the metabolism of nitrogen-containing (mainly amino acids) compounds by animals

Dicarboxylic acid, responsible for the pleasantly sour taste of fruits

Intermediate metabolite in plants and microorganism

$-$

$-$

Flavouring ingredient for food; found in blood and urine

Monocarboxylic $\beta$-hydroxy acid metabolized from leucine 
Table 3 (continued)

\begin{tabular}{lll}
\hline Methanol & $\%$ & Properties (based on El-Sayed 2019) \\
\hline p-Hydroxybenzoic acid & 0.17 & Allomone and pheromone of Coleoptera and Hymenoptera \\
Pantothenic acid & 0.05 & Amide between pantoic acid and $\beta$-alanine \\
alpha-Aminoadipic acid & 0.03 & Intermediate in the metabolism of lysine and saccharopine (protein precursor) \\
\hline
\end{tabular}

The unusual cell wall structure seems to be a common feature among the section Lepidorhiza and sheds more light on secretion in sapromyophilous Orchidaceae. The odour composition seems to mimic the odour of carcasses described previously in stapeliads (Jürgens et al. 2006; Płachno et al. 2010). Furthermore, the reddish and purplish colour together with the echinate texture of the labellum reinforce the scent mimicry. The importance of both floral visual and olfactory features in attracting flies is explained by the experimental data carried out by Beaman et al. (1988). After removing visual cues, blue bottle flies were present on the flowers of Rafflesia pricei only $35 \%$ of the time. Likewise, when fragrance was removed, flies were present only $7-47 \%$ of the time (depending on the effectiveness of fragrance removal). When both olfactory and visual attractants were present, blue bottle flies were noted on the flowers for $95 \%$ of the observation time. It is of interest whether correlation of olfactory and visual effects are common in different sapromyophilous species. For Orchidaceae, such analyses of fly-pollinated species are still lacking.

Acknowledgements This work was supported by University of Gdańsk, Faculty of Biology, Poland-The Young Scientist Project 538-L160B268-16.

Open Access This article is distributed under the terms of the Creative Commons Attribution 4.0 International License (http:// creativecommons.org/licenses/by/4.0/), which permits unrestricted use, distribution, and reproduction in any medium, provided you give appropriate credit to the original author(s) and the source, provide a link to the Creative Commons license, and indicate if changes were made.

\section{References}

Adeosun CB, Olaseinde SA, Opeifa AO, Atolani O (2013) Essential oil from the stem bark of Cordia sebestena scavenges free radicals. J Acute Med 3:138-141. https://doi.org/10.1016/j.jacme.2013.07.002

Arnould C, Malosse C, Signoret JP, Descoins C (1998) Which chemical constituents from dog feces are involved in its food repellent effect in sheep? J Chem Ecol 24:559-576. https://doi.org/10.1023/A: 1022321104758

Baker HG, Baker I (1983) Floral nectar sugar constituents in relation to pollinator type. In: Jones CE, Little RJ (eds) Handbook of experimental pollination biology. Van Nostrand Reinhold Company Inc., New York, pp 117-141

Baker HG, Baker I (1990) The predictive value of nectar chemistry to the recognition of pollinator types. Israel J Bot 39:157-166
Baker HG, Baker I, Hodges SA (1998) Sugar composition of nectar and fruits consumed by birds and bats in the tropics and subtropics. Biotropica 30:559-586

Beaman RS, Decker PJ, Beaman JH (1988) Pollination of Rafflesia (Rafflesiaceae). Am J Bot 75:1148-1162

Borba E, Semir J (1998) Wind-assisted fly pollination in three Bulbophyllum (Orchidaceae) species occurring in the Brazilian Campos Rupestres. Lindleyana 13:203-218

Bronner R (1975) Simultaneous demonstration of lipid and starch in plant tissues. Stain Technol 50:1-4

Christensen DE (1994) Fly pollination in the Orchidaceae. In: Arditti J (ed) Orchid biology: reviews and perspectives, vol VI. Wiley, New York, pp 415-454

Christie WW (1994) Gas chromatography and lipids. The Oily Press, Ayr

Curran AM, Rabin SI, Prada PA, Furton KG (2005) Comparison of the volatile organic compounds present in human odor using SPMEGC/MS. J Chem Ecol 31(7):1607-1619. https://doi.org/10.1007/ s10886-005-5801-4

Davies KL, Stpiczyńska M (2014) Labellar anatomy and secretion in Bulbophyllum Thouars (Orchidaceae: Bulbophyllinae) sect. Racemosae Benth \& Hook f. Ann Bot 114(5):889-911. https://doi. org/10.1093/aob/mcu153

Dobson HEM (2006) Relationship between floral fragrance composition and type of pollinator. In: Dudareva N, Pichersky E (eds) Biology of floral scent. CRC Press, Boca Raton, pp 147-198

Eigenbrode SD, Espelie KE (1995) Effects of plant epicuticular lipids on insect herbivores. Annu Rev Entomol 40:171Y194

Elisens WJ, Freeman CE (1988) Floral nectar sugar composition and pollinator type among New World genera in tribe Antirrhineae (Scrophulariaceae). Am J Bot 75:971-978

El-Sayed AM (2019) The pherobase: database of pheromones and semiochemicals. http://www.pherobase.com, 2003-2019, access from 01. 05.2018

Endress PK (1994) Diversity and evolutionary biology of tropical flowers. Cambridge University Press, Cambridge

European Chemicals Agency (2019) https://echa.europa.eu/substanceinformation/-/substanceinfo/100.004.261, accessed on from 21.02. 2019

Evershed RP (1992) Gas chromatography of lipids. In: Hamilton RJ, Hamilton S (eds) Lipid analysis. A practical approach. Oxford University Press, Oxford

Feder N, O'Brien TP (1968) Plant microtechnique: some principles and new methods. Am J Bot 55:123-142. https://doi.org/10.2307/ 2440500

Formisano C, Senatore F, Porta GD, Scognamiglio M, Bruno M, Maggio A, Rosselli S, Zito P, Sarajeva M (2009) Headspace volatile composition of flowers of Caralluma europaea N. E. Br. (Apocynaceae). Mol 14:4597-4613. https://doi.org/10.3390/ molecules 14114597

Gahan PB (1984) Plant histochemistry and cytochemistry: an introduction. Academic Press, London

Gikonyo NK, Hassanali A, Njagi PGN, Gitu PM, Midiwo JO (2002) Odor composition of preferred (buffalo and ox) and nonpreferred (waterbuck) hosts of some savanna tsetse flies. J Chem Ecol 28: 969-981. https://doi.org/10.1023/A:1015205716921 
Goodrich BS, Hesterman ER, Shaw KS, Mykytowycz R (1981) Identification of some volatile compounds in the odour of faecal pellets of the rabbit, Oryctolagus cuniculus. J Chem Ecol 7: $817-827$

Gopal JV, Subashini E, Kannabiran K (2013) Extraction of quinone derivative from Streptomyces sp. VITVSK1 isolated from Cheyyur saltpan, Tamilnadu, India. J Korean Soc Appl Biol Chem 56:361367. https://doi.org/10.1007/s13765-013-3052-6

Heslop-Harrison Y (1977) The pollen stigma interaction: pollen tube penetration in Crocus. Ann Bot 41:913-922

Jensen W (1962) Botanical histochemistry. Freeman, San Francisco

Johansen DA (1940) Plant microtechnique. McGraw-Hill Book Company, New York

Johnson SD, Jürgens A (2010) Convergent evolution of carrion and faecal scent mimicry in fly-pollinated angiosperm flowers and a stinkhorn fungus. S Afr J Bot 76:796-807. https://doi.org/10.1016/j.sajb. 2010.07.012

Jürgens A, Dötterl S, Meve U (2006) The chemical nature of fetid floral odours in stapeliads (Apocynaceae-Asclepiadoideae-Ceropegieae). New Phytol 172:452-468. https://doi.org/10.1111/j.1469-8137. 2006.01845.x

Kim S, Chen J, Cheng T, Gindulyte A, He J, He S, Li Q, Shoemaker BA, Thiessen PA, Yu B, Zaslavsky L, Zhang J, Bolton EE (2019) PubChem 2019 update: improved access to chemical data. Nucleic Acids Res 47:D1102-D1109. https://doi.org/10.1093/nar/gky1033

Kite GC (1995) The floral odour of Arum maculatum. Biochem Syst Ecol 23:343-354

Kowalkowska AK, Margońska HB, Kozieradzka-Kiszkurno M (2010) Comparative anatomy of the lip spur and additional lateral sepal spurs in a three-spurred form (f. fumeauxiana) of Anacamptis pyramidalis. Acta Biol Cracov Ser Bot 52(1):13-18

Kowalkowska AK, Margońska HB, Kozieradzka-Kiszkurno M, Bohdanowicz J (2012) Studies on the ultrastructure of a threespurred fumeauxiana form of Anacamptis pyramidalis. Plant Syst Evol 298:1025-1035. https://doi.org/10.1007/s00606-012-0611-y

Kowalkowska AK, Kozieradzka-Kiszkurno M, Turzyński S (2015a) Morphological, histological and ultrastructural features of osmophores and nectary of Bulbophyllum wendlandianum (Kraenzl.) Dammer (B. section Cirrhopetalum Lindl., Bulbophyllinae Schltr., Orchidaceae). Plant Syst Evol 301:609622. https://doi.org/10.1007/s00606-014-1100-2

Kowalkowska AK, Kostelecka J, Bohdanowicz J, Kapusta M, Rojek J (2015b) Studies on floral nectary, tepals' structure, and gynostemium morphology of Epipactis palustris (L.) Crantz (Orchidaceae). Protoplasma 252:321-333. https://doi.org/10.1007/ s00709-014-0668-2

Kowalkowska AK, Turzyński S, Kozieradzka-Kiszkurno M, Wiśniewska N (2017) Floral structure of two species of Bulbophyllum section Cirrhopetalum Lindl.: B. weberi Ames and B. cumingii (Lindl.) Rchb. f. (Bulbophyllinae Schltr., Orchidaceae). Protoplasma 254(3):1431-1449. https://doi.org/10.1007/s00709-016-1034-3

Krawczyk E, Rojek J, Kowalkowska AK, Kapusta M, Znaniecka J, Minasiewicz J (2016) Evidence for mixed sexual and asexual reproduction in the rare European mycoheterotrophic orchid Epipogium aphyllum, Orchidaceae (ghost orchid). Ann Bot 118:159-172. https://doi.org/10.1093/aob/mcw084

Kugler H (1951) Blutenokologische Untersuchungen mit Goldfliegen (Lucilien). Ber Deut Bot Ges 64:327-341

Kurose K, Yatagai M (2005) Components of the essential oils of Azadirachta indica A. Juss, Azadirachta siamensis Velton, and Azadirachta excelsa (Jack) Jacobs and their comparison. J Wood Sci 51:185. https://doi.org/10.1007/s10086-004-0640-4

Lammers TG, Freeman CE (1986) Ornithophily among the Hawaiian Lobelioideae (Campanulaceae): evidence from floral nectar sugar composition. Am J Bot 73:1613-1619
Lombarkia N, Derridj S (2002) Incidence of apple fruit and leaf surface metabolites on Cydia pomonella oviposition. Entomol Exp Appl 104:79-87. https://doi.org/10.1023/A:1021227318705

Meve U, Liede S (1994) Floral biology and pollination in stapeliadsnew results and a literature review. Plant Syst Evol 192:99-116. https://doi.org/10.1007/BF00985911

Müller C, Riederer M (2005) Plant surface properties in chemical ecology. J Chem Ecol 31(11):2621-2651. https://doi.org/10.1007/ s10886-005-7617-7

Naczk AM, Kowalkowska AK, Wiśniewska N, Haliński ŁP, Kapusta M, Czerwicka M (2018) Floral anatomy, ultrastructure and chemical analysis in Dactylorhiza incarnata/maculata complex (Orchidaceae). Bot J Linn Soc 187(3):512-536. https://doi.org/10. 1093/botlinnean/boy027

Nunes ELP, Smidt EC, Stützel T, Coan AI (2014) What do floral anatomy and micromorphology tell us about Neotropical Bulbophyllum section Didactyle (Orchidaceae: Bulbophyllinae)? Bot J Linn Soc 175: 438-452. https://doi.org/10.1111/boj.12176

Nunes ELP, Smidt EC, Stützel T, Coan AI (2015) Comparative floral micromorphology and anatomy of species of Bulbophyllum section Napelli (Orchidaceae), a Neotropical section widely distributed in forest habitats. Bot J Linn Soc 177:378-394. https://doi.org/10. 1111/boj.12253

O'Donoghue JL (ed) (1985) Neurotoxicity of industrial and commercial chemicals. Volume I. CRC Press, Inc., Boca Raton, p 129

OECD (2001) SIAM 13, 6-9.11.2001. https:/hpvchemicals.oecd.org/ui/ handler.axd? id=020d85e4-1410-4570-89c5-17d4aa9f5e7d, accessed on 21.02.2019

Omage K, Azeke MA, Omage SO (2018) Evaluation of the efficacy of Acalypha wilkesiana leaves in managing cardiovascular disease risk factors in rabbits exposed to salt-loaded diets. Phytomedicine 4:1. https://doi.org/10.1186/s40816-018-0060-4

Ong P, Tan KH (2011) Fly pollination of four Malaysian species of Bulbophyllum (section Sestochilus) - B. lasianthum, B. lobbii, $B$. subumbellatum and B. virescens. Malesian Orchid J 8:103110

Ong P, Tan KH (2012) Three species of Bulbophyllum section Racemosae pollinated by Drosophila flies. Malesian Orchid J 9:45-50

Paiva EAS (2016) How do secretory products cross the plant cell wall to be released? A new hypothesis involving cyclic mechanical actions of the protoplast. Ann Bot 117:533-540. https://doi.org/10.1093/ aob/mcw012

Percival MS (1965) Floral biology. Oxford New York, Pergamon

Perret M, Chautems A, Spichiger R, Peixoto M, Savolainen V (2001) Nectar sugar composition in relation to pollination syndromes in Sinningieae (Gesneriaceae). Ann Bot 87(2):267-273. https://doi. org/10.1006/anbo.2000.1331

Płachno BJ, Świątek P, Szymczak G (2010) Can a stench be beautiful? osmophores in stem-succulent stapeliads (ApocynaceaeAsclepiadoideae-Ceropegieae-Stapeliinae). Flora 205:101-105. https://doi.org/10.1016/j.flora.2009.01.002

Pridgeon AM, Cribb JP, Chase MW, Rasmussen FN (2014) Genera Orchidacearum Volume 6 Epidendroidae (Part Three). Oxford University Press, Oxford

Reynolds ES (1963) The use of lead citrate at high $\mathrm{pH}$ as an electronopaque stain in electron microscopy. J Cell Biol 17:208-212

Ruzin S (1999) Plant microtechnique and microscopy. Oxford University Press, New York

Spurr AR (1969) A low-viscosity epoxy resin embedding medium for electron microscopy. J Ultrastruct Res 26:31-43. https://doi.org/10. 1016/S0022-5320(69)90033-1

Statheropoulos M, Spiliopoulou C, Agapiou A (2005) A study of volatile organic compounds evolved from the decaying human body. Forensic Sci Int 153:147-155. https://doi.org/10.1016/j.forsciint. 2004.08.015 
Stern WL, Curry KJ, Pridgeon AM (1987) Osmophores of Stanhopea (Orchidaceae). Am J Bot 74:1323-1331. https://doi.org/10.2307/ 2444310

Stiles FG, Freeman CE (1993) Patterns in floral nectar characteristics of some bird-visited plant species from Costa Rica. Biotropica 25:191205

Stpiczyńska M, Davies KL (2016) Evidence for the dual role of floral secretory cells in Bulbophyllum. Acta Biol Cracov Ser Bot 58:5769. https://doi.org/10.1515/abcsb-2016-0013

Stpiczyńska M, Davies KL, Kamińska M (2015) Diverse labellar secretions in African Bulbophyllum (Orchidaceae: Bulbophyllinae) sections Ptiloglossum, Oreonastes and Megaclinium. Bot J Linn Soc 179:266-287. https://doi.org/10.1111/boj.12315

Święczkowska E, Kowalkowska AK (2015) Floral nectary anatomy and ultrastructure in mycoheterotrophic plant_Epipogium aphyllum Sw. (Orchidaceae). Sci World J 15:1-11. ID 201702. https://doi. org $/ 10.1155 / 2015 / 201702$

Tan KH, Nishida R (2007) Zingerone in the floral synomone of Bulbophyllum baileyi (Orchidaceae) attracts Bactrocera fruit flies during pollination. Biochem Syst Ecol 35:334-341. https://doi.org/ 10.1016/j.bse.2007.01.013

Teixeira SDP, Borba EL, Semir J (2004) Lip anatomy and its implications for the pollination mechanisms of Bulbophyllum species (Orchidaceae). Ann Bot 93:499-505. https://doi.org/10.1093/aob/ mch072
Vogel S (2001) Flickering bodies: floral attraction by movement. Beitr Biol Pflanzen 72:89-154

Wishart DS, Feunang YD, Marcu A, Guo AC, Liang K, VázquezFresno R, Sajed T, Johnson D, Li C, Karu N, Sayeeda Z, Lo E, Assempour N, Berjanskii M, Singhal S, Arndt D, Liang Y, Badran H, Grant J, Serra-Cayuela A, Liu Y, Mandal R, Neveu V, Pon A, Knox C, Wilson M, Manach C, Scalbert A (2018) HMDB 4.0: the human metabolome database for 2018. Nucleic Acids Res 4(46(D1)):D608-D617. https://doi.org/10.1093/nar/ gkx1089

Wiśniewska N, Kowalkowska AK, Kozieradzka-kiszkurno M, Krawczyńska AT, Bohdanowicz J (2018) Floral features of two species of Bulbophyllum section Lepidorhiza Schltr.: B. levanae Ames and B. nymphopolitanum Kraenzl. (Bulbophyllinae Schltr., Orchidaceae). Protoplasma 255:485-499. https://doi.org/10.1007/ s00709-017-1156-2

Wood J (2005) Bulbophyllum echinolabium. Curtis's Bot Mag 22:1-87. https://doi.org/10.1111/j.1355-4905.2005.00459.x

Publisher's note Springer Nature remains neutral with regard to jurisdictional claims in published maps and institutional affiliations. 